\title{
Prognostic significance of Oct4 and Sox2 expression in hypopharyngeal squamous cell carcinoma
}

\author{
Nan Ge ${ }^{1,2+}$, Huan-Xin Lin ${ }^{1,2+}$, Xiang-Sheng Xiao ${ }^{1,3+}$, Ling Guo ${ }^{1,4}$, Hui-Min Xu ${ }^{1,2}$, Xin Wang ${ }^{1,2}$, Ting Jin ${ }^{1,2}$, Xiu-Yu Cai ${ }^{1,2}$, \\ Yi Liang ${ }^{1}$, Wei-Han $\mathrm{Hu}^{1,2^{*}}$, Tiebang Kang ${ }^{1 *}$
}

\begin{abstract}
Background: Oct4 and Sox2 are two major transcription factors related to the stem cell self-renewal and differentiation. The aim of this study was to examine the association between Oct4 and Sox2 expression levels with both the clinicopathological characteristics and prognoses of patients with hypopharyngeal squamous cell carcinoma.

Method: Tumor tissue samples from 85 patients with hypopharyngeal squamous cell carcinoma were collected, and the clinical follow-up data of these patients were recorded, and expression status of Oct4 and Sox2 were examined in these tissue samples by immunohistochemistry (IHC).

Results: Oct4 expression was found to be an independent predictive factor for overall survival $(p=0.004)$ in patients with hypopharyngeal squamous cell carcinoma and was independently related to loco-regional control $(p=0.001)$. Although Sox2 expression status showed no significant association with overall survival $(p=0.166)$, disease-free survival $(p=0.680$ ) or loco-regional control $(p=0.383)$, when using a subgroup analysis, the subgroup with both high Oct4 and Sox2 expression had the best prognosis $(p=0.000)$. Sox2 expression could be a potential prognostic predictor for patients with hypopharyngeal squamous cell carcinoma. Simultaneous analyses of Oct4 and Sox2 expression could be more effective in evaluating the prognoses of patients with hypopharyngeal squamous cell carcinoma.
\end{abstract}

Conclusion: Oct4 expression is an independent predictive factor for patients with hypopharyngeal squamous cell carcinoma, suggesting that Oct4 expression may be a useful indicator for predicting the prognosis of hypopharyngeal squamous cell carcinoma.

\section{Background}

Head and neck squamous cell carcinoma, including hypopharyngeal squamous cell carcinoma, is one of the most common cancers worldwide and is associated with low survival and high morbidity [1,2]. Characterized by an aggressive growth pattern and lack of obvious early symptoms, hypopharyngeal squamous cell carcinoma is a cancer with the lowest survival rates among the head and neck subsites [3,4]. Although the standard therapy of surgery plus postoperative radiation results in a

\footnotetext{
* Correspondence: huweihan@126.com; kangtb@mail.sysu.edu.cn

+ Contributed equally

${ }^{1}$ State Key Laboratory of Oncology in South China, Cancer Center of Sun

Yat-Sen University, Guangzhou 510060, China

Full list of author information is available at the end of the article
}

5-year survival rate of $40-50 \%$, most patients have nonresectable tumors when they are diagnosed [5]. Interestingly, the high mortality rate of patients is mainly due to poor loco-regional control, including local tissue invasion by the primary tumor and regional lymph node involvement rather than distant metastasis [6].

The cancer stem cell (CSC) hypothesis posits that tumors may be initiated and maintained by a subset of cells that maintain or acquire stem-cell properties and that each tumor contains a small subpopulation of cells that have the ability to differentiate into multiple cell lineages and self-renew $[7,8]$. Indeed, cancer stem cells or cancer stem-like cells have been identified in several solid tumor types such as breast cancer and colon cancer
Ciomed Central

C 2010 Ge et al; licensee BioMed Central Ltd. This is an Open Access article distributed under the terms of the Creative Commons Attribution License (http://creativecommons.org/licenses/by/2.0), which permits unrestricted use, distribution, and reproduction in any medium, provided the original work is properly cited. 
$[9,10]$. This subpopulation is closely associated not only with carcinogenesis, but also with recurrence and metastasis of tumors [7]. However, there is no sufficient evidence for putative cancer stem cells in hypopharyngeal cancer, and this may be important to elucidate carcinogenesis, to analyze prognosis, and to establish new therapeutic approaches for this cancer type.

Oct4 is a major member of the POU domain transcription factors, which are required for the self-renewal characteristics and differentiation potential of pluripotent embryonic stem and germ cells $[11,12]$. Recent data show that cells expressing high levels of Oct4 are present in breast cancer, bladder cancer and oral squamous cell carcinoma and are associated with a worse prognosis [13-15]. Sox2 is also a major transcription factor belonging to group B of the SOX family and is essential to maintain cell proliferative potential. Unlike Oct4, Sox2 is also expressed in some mature neurons $[16,17]$. On one hand, Sox2 can promote the proliferation of breast cancers and gliomas $[18,19]$. On the other hand, elimination of Sox 2 can lead to gastric cancer [20]. As a transcription factor in the Sox family, Sox2 protein must bind with other proteins, such as Oct4, to regulate DNA transcription [21,22]. In this study, we evaluated Oct4 and Sox 2 expression using immunohistochemical staining of tumor tissues from patients with hypopharyngeal squamous cell carcinoma and analyzed the association between expression of Oct4/ Sox2, clinicopathological characteristics and prognosis of hypopharyngeal squamous cell carcinoma.

\section{Methods}

\section{Patients and tissue samples}

This study was approved by the Institutional Review Board and Human Ethics Committee of Sun Yet-sen University Cancer Center. A total of 85 patients were included with histologically confirmed squamous cell carcinoma of the hypopharynx who were treated from 2002 to 2004 at the Sun Yet-sen University Cancer Center. Relevant clinical pathologic features (Table 1) were obtained from the patients' files and/or by telephone interviews with the patient or their relatives. Tumor types and histologicalgrade classifications were designated according to World Health Organization classification of tumors: pathology and genetics of head and neck tumors [23].

\section{Immunohistochemistry (IHC) staining}

Immunohistochemistry was performed on 4- $\mu \mathrm{m}$-thick routinely processed paraffin sections. Oct 4 was detected using a rabbit polyclonal anti-Oct4a antibody (Cell signaling, \#2890, UK, dilution 1:100). Sox-2 was detected using a rabbit polyclonal anti-Sox antibody (Cell signaling, \#3579, UK, dilution 1:100). A total of 85 formalinfixed, paraffin-embedded hypopharyngeal squamous cell carcinoma tissue samples were dried overnight at $56^{\circ} \mathrm{C}$.
Table 1 The expressions of Oct4 and Sox 2 and their relationships with clinicopathological characteristics

\begin{tabular}{llllll}
\hline Features & $\begin{array}{r}\text { No. } \\
\text { patients }\end{array}$ & OCT4 & $P^{a}$ & SOX2 & $P^{a}$ \\
& & & & \\
& & & High Low Low
\end{tabular}

Gender

Female

Male

Age (years) ${ }^{b}$

$<60$

$\geq 60$

Histological grade

Well

Moderately

Poorly

$\operatorname{sCCA}^{\mathrm{C}}(\mathrm{ng} / \mathrm{ml})$

$\leq 1$

$>1$

$\mathrm{TSGF}^{\mathrm{d}}(\mathrm{ng} / \mathrm{ml})$

$\leq 70$

$>70$

T Stage

$1 \sim 2$

$\begin{array}{ccc}1 & 0 & 1 \\ 84 & 14 & 70\end{array}$

$-$

$1 \quad 0$

$66 \quad 18$

$3 \sim 4$

$\begin{array}{lll}41 & 7 & 34\end{array}$

0.885

$35 \quad 6$

0.154

$\begin{array}{lllll}44 & 7 & 37 & 32 & 12\end{array}$

$\begin{array}{llllll}34 & 5 & 29 & 0.572 & 28 & 6\end{array}$

0.030

$\begin{array}{lllll}39 & 8 & 31 & 33 & 6\end{array}$

$\begin{array}{lllll}12 & 1 & 11 & 6 & 6\end{array}$

43

$\begin{array}{lll}43 & 8 & 35 \\ 21 & 2 & 19\end{array}$

0.348

349

0.794

$21 \quad 2 \quad 19$

$33 \quad 4 \quad 29$

0.298

249

0.230

$\begin{array}{llll}22 & 5 & 17 & 19\end{array}$

0.734

Cervical lymph node metastasis

Positive

Negative

21318

0.756

$\begin{array}{ll}16 & 5 \\ 51 & 13\end{array}$

TNM Stage

$|\sim| \mid$

III IV

Treatment Type

$\mathrm{L}+\mathrm{N}$

$\mathrm{L}+\mathrm{N}+\mathrm{R}$

$\mathrm{L}+\mathrm{N}+\mathrm{C}$

$L+N+R+C$

$N+R$

$N+R+C$

$\mathrm{R}$

$R+C$

C

No treatment or

tracheotomy

${ }^{a}$ Chi-square test.

${ }^{b}$ Patients were divided according to the median values of age.

c SCCA, Squamous Cell Carcinoma Antigen.

d TSGF, Tumor Supplied Group of Factor.

e $\mathrm{L}=$ Laryngectomy, $\mathrm{N}=$ Neck dissection, $\mathrm{R}=$ Radiotherapy, $\mathrm{C}=$ Chemotherapy.

After deparaffinization and rehydration, sections were heat-pretreated in a citrate buffer $\left(92^{\circ} \mathrm{C}\right.$ in microwave oven) and incubated in $3 \% \mathrm{H}_{2} \mathrm{O}_{2}$ to block endogenous peroxidase activity. Then the sections were examined by immunostaining using the primary antibodies overnight at $4^{\circ} \mathrm{C}$ in a humidity chamber. The avidin-biotin 
technique was applied using DAB for visualization and hematoxylin for nuclear counterstaining. Negative controls were prepared by omitting the primary antibody. Histological and IHC evaluation were independently performed by two pathologists without knowledge of the clinicopathological outcomes of the patients. Slides with indeterminate evaluation were re-evaluated, and a consensus was reached. Briefly, each slide was examined in its entirety under a light microscope, and an initial score was assigned which represented the estimated proportion of positive tumor cells $(0$ : none; $1:<1 / 4 ; 2: 1 / 4$ to $1 / 2 ; 3$ : $1 / 2$ to $3 / 4$; and $4:>3 / 4$ ). Next, an intensity score was assigned which represented the average intensity of staining of the positive tumor cells ( 0 , none; 1 , weak; 2 , intermediate; and 3, strong). The proportion and intensity scores were then added to obtain a total score, which ranged from 0 to 7 . Specimens were categorized into one of two groups according to their overall scores: (1) low expression, < 4 points; (2) high expression, 4-7 points.

\section{Statistical methods}

Statistical analysis was performed using the SPSS 17.0 software package for Windows. The $\chi^{2}$ test was used to evaluate categorical variables. Associations between clinicopathological features and immunohistochemical Oct4 or Sox 2 expression were analyzed using the logistic regression model with the presence of overall survival as the dependent variable. Multivariate survival analyses were performed with the Cox regression model. Overall survival (OS) was measured from the onset of treatment to the date of death or the survival status at the last date of follow-up. The loco-regional control (LRC) was the interval from the onset of treatment to the date of recurrence. Recurrence was defined as local tissue invasion by the primary tumor or regional lymph node involvement. Disease-free survival (DFS) was defined as the interval between the onset of treatment and the date when recurrence or metastasis was diagnosed. OS, LRC and DFS probabilities were estimated by the KaplanMeier method and the significance of differences were assessed by the log-rank test. A P-value $<0.05$ was considered statistically significant, and a P-value $<0.01$ was considered strongly statistically significance.

\section{Results}

\section{Clinicopathological features}

Table 1 presents a summary of sex, age, tumor stage, histological grade, and the status of SCCA (Squamous Cell Carcinoma Antigen) as well as TSGF (Tumor Supplied Group of Factor). In this study, there were 85 hypopharyngeal carcinoma patients consisting of 84 males and 1 female. The median age was 60 years (range: $37-82$ years). According to the 6th Edition of the International Union Against Cancer (UICC) TNM classification system, there were 7 Stage II patients, 24 Stage III patients, and 54 Stage IV patients, as shown in Table 2. Recurrences were confirmed by histopathology or visual examination and were found to have occurred in 72 patients. The median time to

Table 2 The relationships between clinicopathological variables and immunohistochemical features with the overall survival

\begin{tabular}{|c|c|c|c|c|c|c|}
\hline \multirow[t]{2}{*}{ Variables } & \multirow{2}{*}{$\begin{array}{l}\text { No. } \\
\text { patients }\end{array}$} & \multicolumn{3}{|c|}{ OS (\%) } & \multirow[t]{2}{*}{$P^{\mathrm{a}}$} & \multirow[t]{2}{*}{$\chi^{2}$} \\
\hline & & $1 y$ & $3 y$ & $5 y$ & & \\
\hline \multicolumn{7}{|l|}{$\operatorname{Age}^{b}(y)$} \\
\hline$<60$ & 41 & 65.9 & 19.5 & 17.1 & 0.555 & 0.348 \\
\hline$\geq 60$ & 44 & 63.6 & 25.0 & 20.5 & & \\
\hline \multicolumn{7}{|l|}{ Histological grade } \\
\hline Well & 34 & 66.7 & 25.0 & 25.0 & 0.996 & 0.008 \\
\hline Moderately & 39 & 67.6 & 20.6 & 17.6 & & \\
\hline Poorly & 12 & 61.5 & 23.1 & 17.9 & & \\
\hline \multicolumn{7}{|l|}{$\operatorname{SCCA}^{\mathrm{C}}(\mathrm{ng} / \mathrm{ml})$} \\
\hline$\leq 1$ & 43 & 69.8 & 18.6 & 16.2 & 0.200 & 1.639 \\
\hline$>1$ & 21 & 71.4 & 19.0 & 14.3 & & \\
\hline \multicolumn{7}{|l|}{$\mathrm{TSGF}^{\mathrm{d}}(\mathrm{ng} / \mathrm{ml})$} \\
\hline$\leq 70$ & 33 & 69.7 & 15.2 & 12.1 & 0.244 & 1.356 \\
\hline$>70$ & 22 & 68.2 & 22.7 & 18.2 & & \\
\hline \multicolumn{7}{|l|}{ T Stage } \\
\hline $1 \sim 2$ & 21 & 90.5 & 23.8 & 14.3 & 0.303 & 1.061 \\
\hline $3 \sim 4$ & 64 & 56.3 & 25.0 & 20.3 & & \\
\hline \multicolumn{7}{|l|}{$\begin{array}{l}\text { Cervical lymph } \\
\text { node metastasis }\end{array}$} \\
\hline positive & 66 & 63.6 & 18.2 & 15.2 & 0.103 & 2.662 \\
\hline negative & 19 & 68.4 & 36.8 & 31.6 & & \\
\hline \multicolumn{7}{|l|}{ TNM Stage } \\
\hline $\mid \sim \|$ & 7 & 100 & 28.5 & 28.5 & 0.678 & 0.173 \\
\hline\|\|$\sim \mid V$ & 78 & 61.5 & 21.8 & 17.9 & & \\
\hline \multicolumn{7}{|l|}{ Oct4 ${ }^{e}$} \\
\hline High Expression & 14 & 85.7 & 71.4 & 57.1 & 0.000 & 15.661 \\
\hline Low Expression & 71 & 60.6 & 12.7 & 11.3 & & \\
\hline \multicolumn{7}{|l|}{ Sox $2^{e}$} \\
\hline High Expression & 67 & 59.7 & 23.9 & 19.4 & 0.683 & 0.166 \\
\hline Low Expression & 18 & 83.3 & 16.7 & 16.7 & & \\
\hline Oct4 \& Sox2 & & & & & 0.000 & 17.991 \\
\hline Both high & 13 & 88.2 & 76.9 & 61.5 & & \\
\hline Either high & 55 & 54.5 & 10.9 & 9.1 & & \\
\hline Both low & 17 & 82.4 & 17.6 & 17.6 & & \\
\hline
\end{tabular}

${ }^{\text {a }}$ Log-rank test.

b Patients were divided according to the median values of age.

c SCCA, Squamous Cell Carcinoma Antigen.

d TSGF, Tumor Supplied Group of Factor.

e Two-sided log rank test with an overall sample size of 85 subjects (of which 71 are in group.

1 and 14 are in group 2) achieves $84 \%$ power at a 0.0500 significance level to detect a difference of 0.5870 between 0.1270 and 0.7140 -the proportions surviving in groups 1 and 2,respectively. This corresponds to a hazard ratio of 0.1632 . These results are based on the assumption that the hazard rates are proportional. 
recurrence was 5.5 months (range 1-50 months). Seventy cancer-related deaths were reported. The median time to death was 17 months (range 0.16-74 months). The reasons for death were local recurrence (62 patients), pulmonary metastases (3 patients), hepatic or abdominal cavity metastases (3 patients) and mediastinal metastases (2 patients).

\section{Follow-up outcome}

The last follow-up date is Sep. $29^{\text {th }}$, 2009, with a median follow-up time 52 months (range 7-69.5 months). The 1 -, 3- and 5-year overall survival rates (OS) were 64.7\%, $22.4 \%, 18.8 \%$, respectively; disease-free survival (DFS) was $24.7 \%, 15.3 \%, 12.9 \%$, respectively. The local-regional control rates were $24.7 \%, 16.5 \%, 15.3 \%$, respectively.

\section{Immunohistochemical expression of Oct4 or Sox 2}

Positive staining for Oct4 and Sox2, mainly localized in the nucleus, were observed in the cancer cells of tumor tissues (Fig. 1). The distribution of immunostaining scores is listed in the Table 1. The highest expression rate of Oct 4 was $9.4 \%$ (8 of 85), whereas that of Sox2 was $71.8 \%$ (61 of 85 ). Furthermore, the expression Oct4 is correlated with the cervical lymph node metastasis $(p=0.007)$ whereas the expression of Sox 2 is correlated with the histological grade $(p=0.03)$, as in Table 1.

\section{Association with prognosis}

Univariate analyses showed no significant association between OS, DFS or LRC and T stage, cervical lymph node metastasis, TNM stage, age, or histological grade (Table 2, 3). Patients with high Oct4 expression had a significantly better prognosis, including longer survival $(p=0.000)$ and lower recurrence rate $(p=0.000)$. Even though Sox 2 expression showed no association with prognosis, the highest overall survival rate was documented in the high Oct4 expression/high Sox2 expression subgroup. The 5 -years overall survival rate was $61.5 \%$ for this group $(p=0.000)$ (Fig. 2).

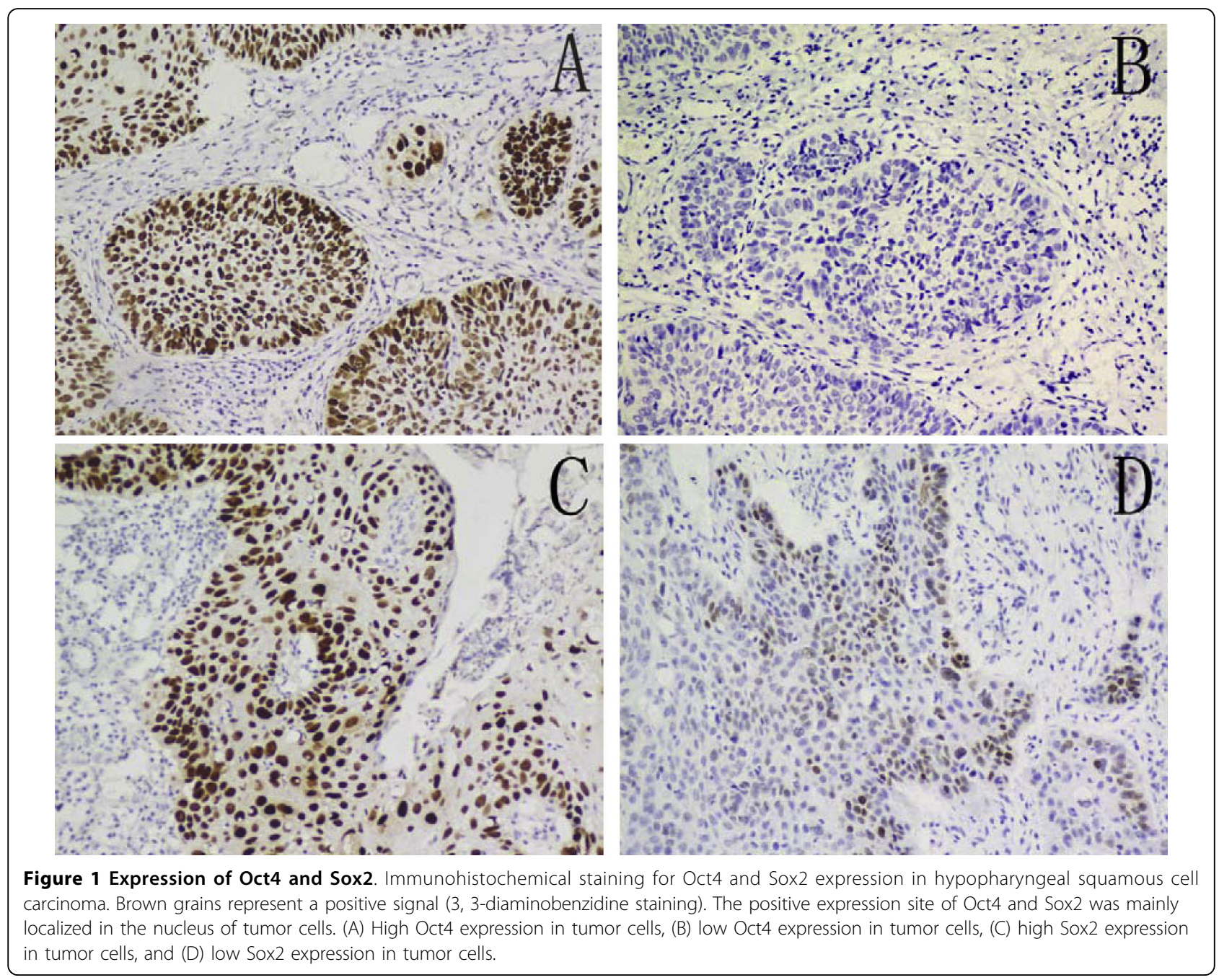


Table 3 The relationships between clinicopathological variables and immunohistochemical features with the disease-free survival and the loco-regional control

\begin{tabular}{lcccc}
\hline Variables & \multicolumn{2}{c}{ DFS } & \multicolumn{2}{c}{ LRC } \\
\cline { 2 - 5 } & $\boldsymbol{P}^{\mathbf{a}}$ & $\boldsymbol{\chi}^{\mathbf{2}}$ & $\boldsymbol{P}^{\mathbf{a}}$ & $\boldsymbol{\chi}^{\mathbf{2}}$ \\
\cline { 4 - 5 } Age $^{\mathrm{b}}$ & 0.340 & 0.911 & 0.398 & 0.713 \\
Histological grade & 0.852 & 0.320 & 0.782 & 0.492 \\
SCCA $^{\mathrm{c}}$ & 0.265 & 1.243 & 0.165 & 1.932 \\
TSGF $^{\mathrm{d}}$ & 0.352 & 0.868 & 0.370 & 0.804 \\
T Stage $_{\text {Cervical lymph node metastasis }}$ & 0.437 & 0.605 & 0.567 & 0.328 \\
TNM Stage $_{\text {Oct4 expression }}$ & 0.050 & 3.832 & 0.106 & 2.610 \\
Sox2 expression & $\mathbf{0 . 0 0 0}$ & 22.275 & $\mathbf{0 . 0 0 0}$ & 20.405 \\
Oct4 \& Sox2 expression & 0.680 & 0.170 & 0.383 & 0.761 \\
\hline a Logrank test & $\mathbf{0 . 0 0 0}$ & 26.331 & $\mathbf{0 . 0 0 0}$ & 22.101 \\
\hline
\end{tabular}

a Log-rank test.

b Patients were divided according to the median values of age.

c SCCA, Squamous Cell Carcinoma Antigen.

${ }^{\mathrm{d}}$ TSGF, Tumor Supplied Group of Factor.

\section{Multivariate analysis}

A multivariate survival analysis was performed with the Cox regression model for each predictor of prognosis to calculate odds ratios, as well as $95 \%$ confidence intervals. The model was simplified in a stepwise fashion by removing variables that had a $p$ value $\geq 0.05$. Only three variables remained statistically significant as independent predictors of OS and LRC in the multivariate analysis. Also, because the variable Oct 4 \& Sox 2 expression consisted of Oct 4 expression and Sox 2 expression, this variable is replaced by Sox 2 expression (Table 4$)$. The results indicate that the expression status of Oct $4(p=0.004)$ was an independent predictive factors for prognoses of hypopharyngeal squamous cell carcinoma patients.

\section{Discussion}

The relationship between cancer cells and normal stem cells is a hot topic in cell biology. There is evidence showing that some cancer cells are functionally heterogeneous
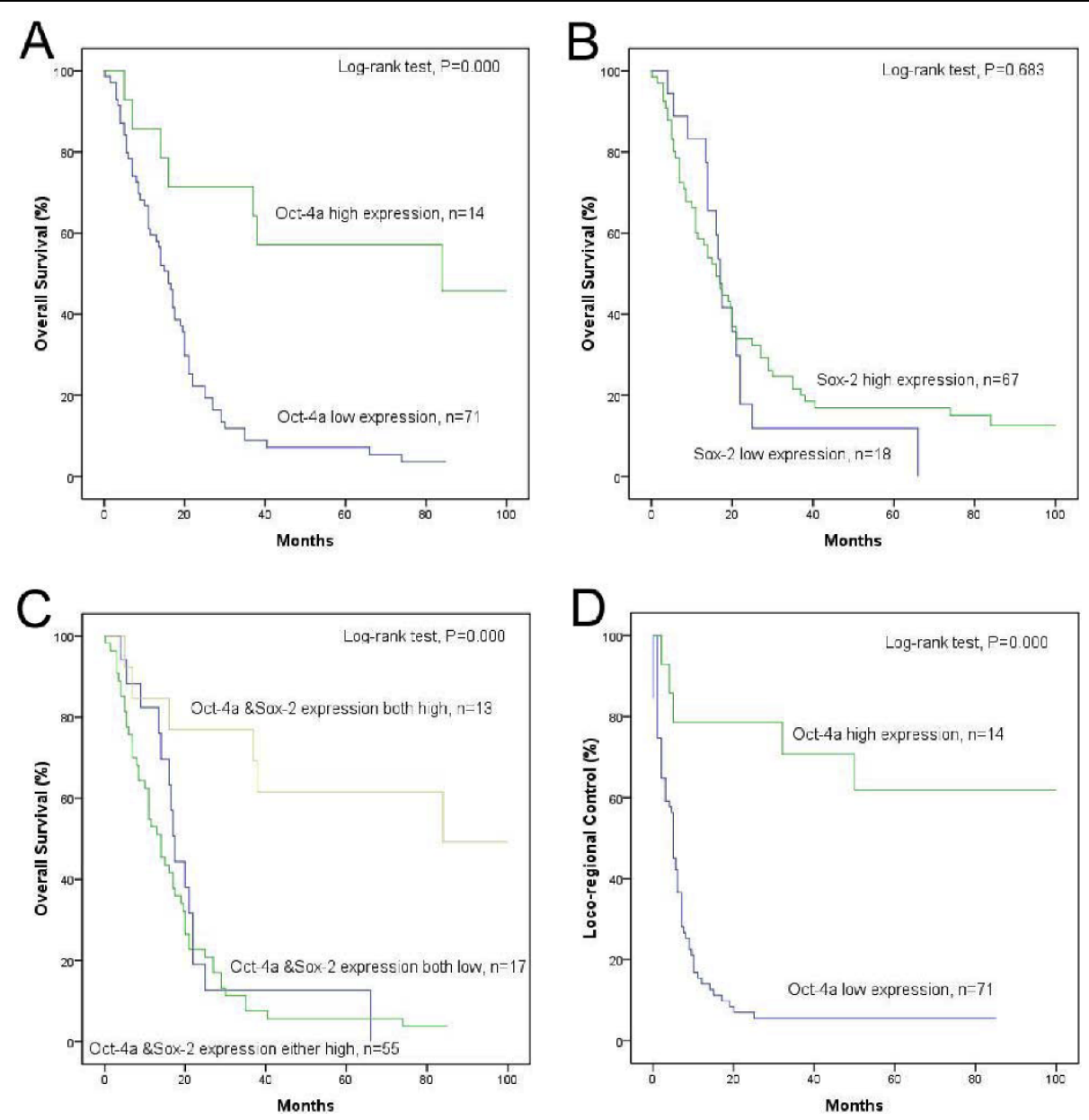

Figure 2 The Kaplan-Meier survival curves. Kaplan-Meier curves for overall survival rates according to (A) Oct4 expression status, (B) Sox2 expression status, (C) combined expression status of Oct4/Sox2 and loco-regional control rates according to (D) Oct4 expression status in hypopharyngeal squamous cell carcinoma. Statistical differences were calculated through log-rank comparisons. 
Table 4 Multivariate analysis

\begin{tabular}{lcccccc}
\hline Variables & \multicolumn{3}{c}{ OS } & & \multicolumn{3}{l}{ LRC } \\
\cline { 2 - 7 } & $\begin{array}{l}\text { Odds } \\
\text { ratio }\end{array}$ & $\mathbf{9 5 \% \mathbf { C l } ^ { \mathbf { a } }}$ & $\boldsymbol{P}^{\mathbf{b}}$ & $\begin{array}{l}\text { Odds } \\
\text { ratio }\end{array}$ & $\mathbf{9 5 \% \mathbf { C l } ^ { \mathbf { a } }}$ & $\boldsymbol{P}^{\mathbf{b}}$ \\
\cline { 2 - 7 } Oct4 & 0.296 & $0.129-$ & $\mathbf{0 . 0 0 4}$ & 0.183 & $0.040-$ & $\mathbf{0 . 0 0 1}$ \\
expression & & 0.679 & & & 0.475 & \\
Sox2 & 0.855 & $0.477-$ & 0.599 & 1.239 & $0.681-$ & 0.485 \\
expression & & 1.532 & & & 2.254 & \\
\hline
\end{tabular}

${ }^{a} \mathrm{Cl}$, Confidence interval.

${ }^{\mathrm{b}}$ Cox regression model.

which confers not only the capacity of self-renewal but also of differentiation and maturation $[7,8]$. This subpopulation of cancer cells may be similar to stem cells or stemlike cells. Oct 4 and Sox 2 have been proven to be two major transcription factors that can render an adult cell capable of being reprogrammed to become a pluripotent stem cell $[12,24,25]$. In addition, the expression of Oct 4 or Sox2 has been reported in the cancer stem-like cells and is related to a cancer patient's prognosis. Taken together, Oct 4 or Sox 2 might play an important role in carcinogenesis and tumor progression and may be used as an indicator of the patient prognosis [13-15,18,19].

In the present study, we found an association between the expression of Oct4 and lymphoid metastasis, whereas the expression of Sox 2 was significantly related to the histological grade of individual hypopharyngeal squamous cell carcinomas. But expression of Oct4 and Sox 2 had no significant association with the $\mathrm{T}$ stages. More importantly, the status of Oct4 expression in tumor tissues served as a significant independent predictor of both OS and recurrence for the patients with hypopharyngeal squamous cell carcinoma. This role as an independent predictor was supported by data that patients with high Oct4 expression survived longer and had a lower recurrence rates. Although the expression of Sox 2 was not associated with prognosis, the subgroup with high expressions of both Oct 4 and Sox 2 presented the highest 5 -year overall survival rate (61.5\%) of all subgroups. These data are supported by the fact that decreased expression of Sox 2 might be related to the carcinogenesis human gastric epithelial cancers [26]. Thus, it may be not surprising that high expression of Oct4 could be an indicator of better prognosis for patients with hypopharyngeal squamous cell carcinoma. In fact, in mouse preimplantation embryos, Stewart CL showed that either an increase above $150 \%$ or a decrease below $50 \%$ of the endogenous Oct4 levels could serve as a trigger for the differentiation of two somatic lineages, indicating that Oct4 functions differently at lower or higher levels [27]. This may also apply for hypopharyngeal squamous cell carcinoma, as shown in this manuscript. However, the roles of Oct4 and Sox2 in hypopharyngeal squamous cell carcinoma still require further investigation.

\section{Conclusion}

Currently, clinical TNM stage is insufficient to predict prognoses of patients with hypopharyngeal squamous cell carcinoma, patients of the same clinical stage often show different clinical course. In this study we demonstrate that Oct4 expression is an independent predictive factor for patients with hypopharyngeal squamous cell carcinoma, suggesting that Oct 4 expression may be a useful indicator for predicting the prognosis of hypopharyngeal squamous cell carcinoma.

\section{Acknowledgements}

We thank Dr. Rong-Zhen Luo, Dr. Ma-Yan Huang and Dr. Mei Li for immunohistochemical analysis. This work was supported by the Natural Science Foundation of Guangdong Province, P. R. China, (To: WHH, No. 9151008901000223) 985 funding from Sun Yat-sun University (To: TK).

\section{Author details}

${ }^{1}$ State Key Laboratory of Oncology in South China, Cancer Center of Sun Yat-Sen University, Guangzhou 510060, China. '2Department of Radiation Oncology, Cancer Center of Sun Yat-Sen University, Guangzhou 510060, China. ${ }^{3}$ Department of Breast Oncology, Cancer Center of Sun Yat-Sen University, Guangzhou 510060, China. ${ }^{4}$ Department of Nasopharyngeal Carcinoma, Cancer Center of Sun Yat-Sen University, Guangzhou 510060, China.

\section{Authors' contributions}

WHH, NG, HXL, LG, TJ, and XYC carried out the cases collection, NG, XW and HMX carried out the immunohistochemical staining work, NG, XSX and YL analyzed results. TK and WHH conceived of the study, participated in its design and coordination and helped to draft the manuscript. All authors read and approved the final manuscript.

\section{Competing interests}

The authors declare that they have no competing interests.

Received: 5 May 2010 Accepted: 12 October 2010

Published: 12 October 2010

\section{References}

1. Jemal A, Siegel R, Ward E, Murray T, Xu J, Thun MJ: Cancer statistics, 2007. CA Cancer J Clin 2007, 57:43-66.

2. Parkin DM, Pisani P, Ferlay J: Global cancer statistics. CA Cancer J Clin 1999, 49:33-64, 1.

3. Lehnerdt GF, Franz P, Zaqoul A, Schmitz KJ, Grehl S, Lang S, Schmid KW, Siffert W, Jahnke K, Frey UH: Overall and relapse-free survival in oropharyngeal and hypopharyngeal squamous cell carcinoma are associated with genotypes of T393C polymorphism of the GNAS1 gene. Clin Cancer Res 2008, 14:1753-1758.

4. Lim YC, Park HY, Hwang HS, Kang SU, Pyun JH, Lee MH, Choi EC, Kim CH: (-)-Epigallocatechin-3-gallate (EGCG) inhibits HGF-induced invasion and metastasis in hypopharyngeal carcinoma cells. Cancer Lett 2008 , 271:140-152.

5. Ozer E, Grecula JC, Agrawal A, Rhoades CA, Young DC, Schuller DE: Longterm results of a multimodal intensification regimen for previously untreated advanced resectable squamous cell cancer of the oral cavity, oropharynx, or hypopharynx. Laryngoscope 2006, 116:607-612.

6. Lothaire P, de Azambuja E, Dequanter D, Lalami Y, Sotiriou C, Andry G, Castro GJ, Awada A: Molecular markers of head and neck squamous cell carcinoma: promising signs in need of prospective evaluation. Head Neck 2006, 28:256-269.

7. Jordan CT, Guzman ML, Noble M: Cancer stem cells. N Engl J Med 2006, 355:1253-1261.

8. Reya T, Morrison SJ, Clarke MF, Weissman IL: Stem cells, cancer, and cancer stem cells. Nature 2001, 414:105-111. 
9. Al-Hajj M, Wicha MS, Benito-Hernandez A, Morrison SJ, Clarke MF: Prospective identification of tumorigenic breast cancer cells. Proc Natl Acad Sci USA 2003, 100:3983-3988.

10. O'Brien CA, Pollett A, Gallinger S, Dick JE: A human colon cancer cell capable of initiating tumour growth in immunodeficient mice. Nature 2007, 445:106-110.

11. Burdon T, Smith A, Savatier P: Signalling, cell cycle and pluripotency in embryonic stem cells. Trends Cell Biol 2002, 12:432-438.

12. Niwa H, Miyazaki J, Smith AG: Quantitative expression of Oct-3/4 defines differentiation, dedifferentiation or self-renewal of ES cells. Nat Genet 2000, 24:372-376.

13. Atlasi Y, Mowla SJ, Ziaee SA, Bahrami AR: OCT-4, an embryonic stem cell marker, is highly expressed in bladder cancer. Int I Cancer 2007, 120:1598-1602.

14. Chiou SH, Yu CC, Huang CY, Lin SC, Liu CJ, Tsai TH, Chou SH, Chien CS, $\mathrm{Ku} \mathrm{HH}$, Lo JF: Positive correlations of Oct-4 and Nanog in oral cancer stem-like cells and high-grade oral squamous cell carcinoma. Clin Cancer Res 2008, 14:4085-4095.

15. Ezeh UI, Turek PJ, Reijo RA, Clark AT: Human embryonic stem cell genes OCT4, NANOG, STELLAR, and GDF3 are expressed in both seminoma and breast carcinoma. Cancer 2005, 104:2255-2265.

16. Bani-Yaghoub M, Tremblay RG, Lei JX, Zhang D, Zurakowski B, Sandhu JK, Smith B, Ribecco-Lutkiewicz M, Kennedy J, Walker PR, Sikorska M: Role of Sox2 in the development of the mouse neocortex. Dev Biol 2006, 295:52-66.

17. Cavallaro M, Mariani J, Lancini C, Latorre E, Caccia R, Gullo F, Valotta M, DeBiasi S, Spinardi L, Ronchi A, et al: Impaired generation of mature neurons by neural stem cells from hypomorphic Sox 2 mutants. Development 2008, 135:541-557.

18. Chen Y, Shi L, Zhang L, Li R, Liang J, Yu W, Sun L, Yang X, Wang Y, Zhang $Y$, Shang $Y$ : The molecular mechanism governing the oncogenic potential of SOX2 in breast cancer. J Biol Chem 2008, 283:17969-17978.

19. Gangemi RM, Griffero F, Marubbi D, Perera M, Capra MC, Malatesta P, Ravetti GL, Zona GL, Daga A, Corte G: SOX2 silencing in glioblastoma tumor-initiating cells causes stop of proliferation and loss of tumorigenicity. Stem Cells 2009, 27:40-48.

20. Otsubo T, Akiyama Y, Yanagihara K, Yuasa Y: SOX2 is frequently downregulated in gastric cancers and inhibits cell growth through cellcycle arrest and apoptosis. Br J Cancer 2008, 98:824-831.

21. Masui $S$, Nakatake $Y$, Toyooka Y, Shimosato D, Yagi R, Takahashi K, Okochi H, Okuda A, Matoba R, Sharov AA, et al: Pluripotency governed by Sox2 via regulation of Oct $3 / 4$ expression in mouse embryonic stem cells. Nat Cell Biol 2007, 9:625-635.

22. Nishimoto M, Miyagi S, Katayanagi T, Tomioka M, Muramatsu M, Okuda A: The embryonic Octamer factor $3 / 4$ displays distinct DNA binding specificity from those of other Octamer factors. Biochem Biophys Res Commun 2003, 302:581-586.

23. Thompson L: World Health Organization classification of tumours: pathology and genetics of head and neck tumours. Ear Nose Throat $J$ 2006, 85:74.

24. Avilion AA, Nicolis SK, Pevny LH, Perez L, Vivian N, Lovell-Badge R: Multipotent cell lineages in early mouse development depend on SOX2 function. Genes Dev 2003, 17:126-140.

25. Nichols J, Zevnik B, Anastassiadis K, Niwa H, Klewe-Nebenius D, Chambers I, Scholer $\mathrm{H}$, Smith A: Formation of pluripotent stem cells in the mammalian embryo depends on the POU transcription factor Oct4. Cell 1998, 95:379-391.

26. Li XL, Eishi Y, Bai YQ, Sakai H, Akiyama Y, Tani M, Takizawa T, Koike M, Yuasa Y: Expression of the SRY-related HMG box protein SOX2 in human gastric carcinoma. Int J Oncol 2004, 24:257-263.

27. Stewart CL: Oct-4, scene 1: the drama of mouse development. Nat Genet 2000, 24:328-330.

doi:10.1186/1479-5876-8-94

Cite this article as: Ge et al:: Prognostic significance of Oct4 and Sox2 expression in hypopharyngeal squamous cell carcinoma. Journal of Translational Medicine 2010 8:94.

\section{Submit your next manuscript to BioMed Central and take full advantage of:}

- Convenient online submission

- Thorough peer review

- No space constraints or color figure charges

- Immediate publication on acceptance

- Inclusion in PubMed, CAS, Scopus and Google Scholar

- Research which is freely available for redistribution

Submit your manuscript at www.biomedcentral.com/submit
Biomed Central 